\title{
CHARACTERIZATION OF B-LACTAMASE GENES IN ESCHERICIA COLI ISOLATED FROM BROILERS
}

\author{
"Fawzia A. Dawoud," Hisham S. Nada," Magdi I. Abdelaziz \\ "-n Khalid I.El ikhnawey \\ "Animal Health Recearch Institute , Tanta branch, Egypt \\ ** Bacteriology,Mycology and Immunology Dep.,Fac.of vet.med. \\ Kafreelsheikh Univ., Egypt. \\ " Pharmacology Dep., Fac. of vet. med., Kafreelsheikh Univ., Egypt \\ Animal Health Recearch Institute, Dokki, Giza, Egypt.
}

\begin{abstract}
Due to intensive use of $\beta$-lactam drugs as therapeutic agents and growth promoting the $\beta$-lactam resistant is developed,and it is primarily developed by $\beta$-lactamases . therefore, the objective of this study was to characterize $\beta$-lactamase genes in E. coli isolated from broilers. A total of 105 sampels isolated from broilers from Gharbia governorates ,28 isolates were positive for E.coli (26.6\%), 15 isolatas were randomly taken and they serogrouped to 7 serotypes (O 55, O78, O 125, O126, O 157, O119:H6, and O1:H7).All isolated strains showed multidrug resistance phenotypes particularly against amoxicillin, erythromycin, doxycyclin, norfloxacin, and colistin sulphate respectively, PCR for the detection of $\beta$-lactamase genes in isolated strains showed that, all isolates contain $\beta$-lactamase genes, 5 isolates contain bla TEM 5 (50\%), 2 isolates contain bla CTX-M 2 (20\%), 3 isolates contain bla OXA 3 (30\%), 2 isolates contain bla SHV 2 (20\%), 1 isolates contain both bla TEM and bla OXA, 2 isolate contain both bla TEM and bla CTX-M and 1 isolate contain three gens bla TEM, bla SHV, and bla CTX-M.
\end{abstract}




\section{INTRODUCTION}

E. coli is a common inhabitant of the human and animal gut and it considered an indicator of fecal contamination in food. $\beta$-lactams are widely used in human and veterinary medicine to treat human and animal infections (Livermore, 1998). This widespread use of antibiotics could be associated with the selection of antibiotic resistance mechanisms in pathogenic and nonpathogenic isolates of E. coli (Sunde and Sorum, 1999). Resistance to $\beta$-lactams in Enterobacteriaceae is mainly due to the production of $\beta$-lactamases which may be encoded either chromosomally or on plasmids (Bradford, 2005). $\beta$-Lactamases are enzymes responsible for many failures of antimicrobial therapy because of the hydrolysisof $\beta$-lactam antibiotics to inert and ineffective agent, The first of these enzymes was recognized by Abraham and Chain in 1940. Resistance to extended-spectrum $\beta$-lactams has been associated with the production of broad-spectrum $\beta$-lactamases such as extendedspectrum $\beta$-lactamases (ESBLs) (Batchelor et al., 2005a). Many types of $\beta$ - lactamases have been described ,but TEM, SHV, OXA, CMY, and CTX-M type $\beta$ - lactamases are the most common in gram-negative bacteria (Bradford,2001), Also all groups of $\beta$ - lactamases were

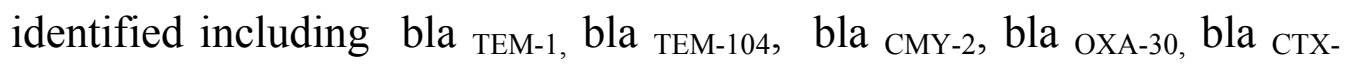
M15, and bla SHV-2 (Ahmed, et al, 2013), Furthermore,bla TEM, bla ${ }_{\mathrm{OXA}}$, and bla ${ }_{\text {CTX-M }}$ were reported in $E$. coli strains isolated from broiler chickens and turkeys in the United Kingdom (Randall et al., 2011), while bla TEM and bla SHV were identified in APEC strains isolated from poultry in Australia (Obeng et al., 2012).

$\overline{\text { Kafrelsheikh Vet. Med. J. Vol. } 12 \text { No. } 2 \text { (2014) }}$ 


\section{MATERIAL AND METHODS}

\section{Sampling, isolation , and identification procedures:}

A total of 105 freshly died broilers in some farms at Gharbia Governorate were transferred to bacteriology laboratory, the Specimens were taken from gall blader, intestin and coloacal swab. The specimens were inoculated onto Nutrient broth and incubated at $37^{\circ} \mathrm{C}$ for $24 \mathrm{~h}$. then subcultured on MacConkey agar medium, the developed pink colonies subcultured into Eosin methylene blue medium and incubated at $37^{\circ} \mathrm{C}$ for $24 \mathrm{~h}$. Developed colonies were subjected to biochemical identification (Developed colonies were subjected to I.M.Vi.C, urease test, and triple sugar iron agar medium) (Baron and Finegold, 1990).

Serotyping of $E$. coli isolates (Cruickshank et al. 1975):

Isolates of $E$. coli were inoculated on semisolid or slope agar (incubated 24 hours at $37^{0} \mathrm{C}$ ), Isolates of $E$. coli subcultured on MacConkey agar (incubated 24 hours at $37^{\circ} \mathrm{C}$ ), 3-5 colonies were inoculated on to $3 \mathrm{ml}$ saline and Put in water bath $100{ }^{0} \mathrm{C}$ for 1 hour to kill the thermo E.coli then centrifuged at $2000 \mathrm{rpm}$, Pour out the supernatant and kept the precipitate then added $0.5 \mathrm{ml}$ saline on it. The serology Carried out as follow, added a drop from the tube on a glass slide and added one drop from the $\mathrm{O}$ monovalent antiserum and mix them using a wooden strike or glass rod. If agglutination occurs this indicated positive reaction. 
Antimicrobial susceptibility testing(disk diffusion) (Bauer et al. 1966):

The antimicrobial sensitivity phenotypes of E.coli isolated srains were determined using Bauer disc diffusion test according to the standereds and interpretive criteria described by CLSI (Clinical and Laboratory Standered Institute, 2005) The following antibiotics were used.

\begin{tabular}{||c||c|}
\hline \multicolumn{1}{|c|}{ Chemotherapeutic agents } & Conc. \\
\hline \hline Amoxicillin/Clavulanic Acid (AMC) & $30 \mu \mathrm{g}$ \\
\hline Amoxicillin (AX) & $10 \mu \mathrm{g}$ \\
\hline Erythromycin (E) & $15 \mu \mathrm{g}$ \\
\hline Gentamicin (GN) & $10 \mu \mathrm{g}$ \\
\hline Doxycyclin (DO) & $30 \mu \mathrm{g}$ \\
\hline Cefotaxime (CTX) & $30 \mu \mathrm{g}$ \\
\hline Colistin sulphate (CT) & $10 \mu \mathrm{g}$ \\
\hline Norfloxacin (NOR) & $10 \mu \mathrm{g}$ \\
\hline
\end{tabular}

The disks were purchased and the results were recorded based on CLSI guidelines (CLSI , 2005). The phenomenon of multidrug resistance is defined as the ability of acell to show resistance to awide variety of structurally and functionally unrelated molecules (Higgins, 2007) We used the term multidrug-resistant E.coli in this work to describe any E.coli isolate showed resistance to more than two classes of antimicrobials.

PCR and DNA sequencing for detection of $\beta$-lactamase genes in isolated strains DNA extraction and purification:

DNA was prepared using boiled lysates, as previously described (Ahmed et al., 2007).

1- An overnight bacterial culture $(200 \mu \mathrm{l})$ was mixed with $800 \mu \mathrm{l}$ of distilled water and boiled for10 min. 
2- The resulting solution was centrifuged at $10.000 \mathrm{rpm}$ for $15 \mathrm{~min}$ or $12.000 \mathrm{rpm}$ for $10 \mathrm{~min}$.

3- The supernatant was used as the DNA template. DNA template was stored at $-20 \circ$ Cuntil further use.

\section{Amplification and cycling protocol for conventional PCR:}

Using of PCR 2x Reddy Mix TM Master Mix (Thermo SCIENTIFIC) with Cat. No. (AB0575/LD-A).

\section{DNA samples were amplified in a total of $50 \mu \mathrm{l}$ as the following:}

- $25 \mu 1$ of PCR master mix $\quad, \quad 2.5 \mu 1$ of forward primer

- $2.5 \mu 1$ of reverse primer $\quad, \quad 10 \mu 1$ of PCR grade water

- $10 \mu 1$ of the template

- PCR cycling program (Ahamed et al. 2007).

- Thermal profile protocol.

\begin{tabular}{|c|c|c|c|c|c|c|c|}
\hline Target & $\begin{array}{c}\text { Final } \\
\text { extention }\end{array}$ & $\begin{array}{c}\text { Cycle } \\
\text { number }\end{array}$ & $\begin{array}{c}\text { Primer } \\
\text { extention }\end{array}$ & Annealling & Denat. & Hot start & Gene \\
\hline 1080Bp & $72^{\circ} \mathrm{C} / 10 \mathrm{~min}$ & 30 & $72^{0} \mathrm{C} / 1 \mathrm{~min}$ & $50^{\circ} \mathrm{C} / 30 \mathrm{Sec}$ & $94^{0} \mathrm{C} / 30 \mathrm{Sec}$ & $94^{0} \mathrm{C} / 10 \mathrm{~min}$ & TEM \\
\hline 795Bp & $72^{0} \mathrm{C} / 10 \mathrm{~min}$ & 30 & $72^{0} \mathrm{C} / 1 \mathrm{~min}$ & $50^{\circ} \mathrm{C} / 30 \mathrm{Sec}$ & $94^{0} \mathrm{C} / 30 \mathrm{Sec}$ & $94^{0} \mathrm{C} / 10 \mathrm{~min}$ & SHV \\
\hline $591 B p$ & $72^{0} \mathrm{C} / 10 \mathrm{~min}$ & 35 & $72^{0} \mathrm{C} / 1 \mathrm{~min}$ & $56^{0} \mathrm{C} / 1 \mathrm{Min}$ & $94^{0} \mathrm{C} / 1 \mathrm{Min}$ & $94^{0} \mathrm{C} / 10 \mathrm{~min}$ & OXA \\
\hline $550 \mathrm{Bp}$ & $72^{\circ} \mathrm{C} / 5 \mathrm{~min}$ & 30 & $72^{\circ} \mathrm{C} / 30 \mathrm{sec}$ & $55^{\circ} \mathrm{C} / 30 \mathrm{sec}$ & $95^{\circ} \mathrm{C} / 30 \mathrm{sec}$ & $95^{0} \mathrm{C} / 10 \mathrm{~min}$ & CTX-M \\
\hline
\end{tabular}

\section{Detection of PCR products (Ahamed et al. 2007).}

Aliquots of amplified PCR products were mixed with gel loading buffer and electrophoresed in $1.5 \%$ agarose gel as shown in the following steps: 
1) The prepared agarose was melted using microwave and left to cool till $55^{\circ} \mathrm{C}$ then ethidium bromide was added by $0.5 \mu \mathrm{g} / \mathrm{ml}$ and poured into the assembled horizontal gel tray after proper installation of the desired comb.

2) The gel was allowed to be solidified at room temperature.

3) TBE buffers that used for preparation of the gel were added into the tank to a level 1-2 mm above the gel layer.

4) The samples and a 100 bp DNA ladder (marker) were loaded in the wells in amount of $8 \mu 1$ of sample with $3 \mu 1$ of loading buffer and introduce $8 \mu \mathrm{l}$ of the ladder, the tank was closed and the power supply was attached.

5) A current of $80 \mathrm{~V}$ for 1 hour was passed on the medi horizontal electrophoresis unit.

6)Specific amplicons were observed under ultraviolet transillumination, compared with the marker.

7) The gel was photographed by a gel documentation system and the datawasanalysed through computer software.

\section{ESBL detection by double-disk synergy test (Ho et al., 1998).}

The first test specifically designed to detect ESBL production in Enterobacteriaceae was the double disk synergy test (DDST). It was initially designed to differentiate between cefotaxime resistant strains, i.e., those overproducing cephalosporinase, and those producing ESBLs. The test is performed on agar with a 30ug disk of cefotaxime(and/or ceftriaxone) and a disk of amoxicillin-clavulanate (containing $10 \mathrm{ug}$ of 
clavulanate) positioned at a distance of $30 \mathrm{~mm}$ (centre to centre) The test is considered as positive when a decreased susceptibility to cefotaxime is combined with a clear-cut enhancement of the inhibition zone of cefotaxime in front of the clavulanate-containing disk, often resulting in acharacteristic shape-zone referred to as 'champagne-cork' or 'keyhole'

\section{RESULTS}

\section{Isolation and identification of $\boldsymbol{E}$.coli isolated from broilers:}

From 105 samples collected from diseased briolers from Gharbia Governrate, the positive sample for E.coli were 28 samples with incidence $26.6 \%$.

Serotyping of $E$. coli isolate:

The result of serological identification of randomly 15 isolates of E.coli from the total positive isolates revealed that, 12 isolates were tybed under 7 different $\mathrm{O}$ serotypes $\left(\mathrm{O}_{55}, \mathrm{O}_{78}, \mathrm{O}_{125}, \mathrm{O}_{1}, \mathrm{O}_{126}, \mathrm{O}_{157}, \mathrm{O}\right.$ 119), while 3 isolates were untyped.

Results of antibiogram (disc diffusion) of eight chemotherapeutic agents on different $E$. coli isolate strains:

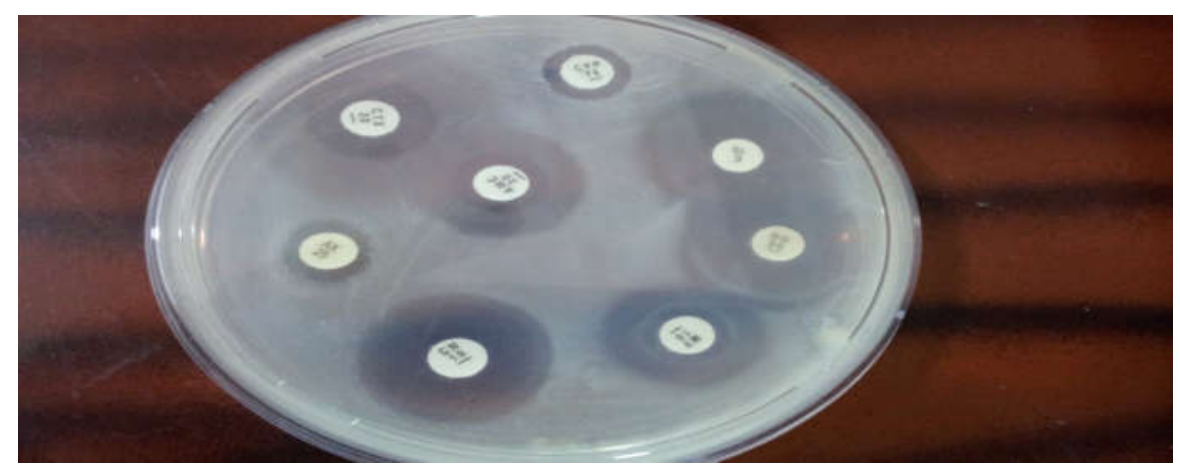

Disc diffusion test

$\overline{\overline{\text { Kafrelsheikh Vet. Med. J. Vol. } 12 \text { No. } 2 \text { (2014) }}}$ 
Sensitivity percentage to each antimicrobial agent were determined (Cefotaxime ,Gentamicin ,Amoxycillin/clavulinic acid were the most effective on E. coli isolated strains with percent $80 \%, 70 \%, 60 \%$ respectively) while Colistinsulphate, Ciprofloxacin, Doxycyclin, Erythromycin were less effective with susceptibility percent $50 \%, 40 \%, 20 \%, 10 \%$ respectively, and Amoxycillin with susceptibility percent $10 \%$.

The most effective antibiotic drug on the tested strains:

\begin{tabular}{|l|c||}
\hline \multicolumn{1}{|c|}{ Effective antibiotic drug } & Strain isolated \\
\hline \hline Cefotaxime & O 157 \\
\hline Cefotaxime & O 78 \\
\hline Cefotaxime & O 1 \\
\hline Colistin sulphate & O 119 \\
\hline Gentamicin & O 125 \\
\hline Cefotaxim, Gentamicin & O 126 \\
\hline Gentamicin & O 55 \\
\hline
\end{tabular}

\section{Detection of resistance genes by PCR.}

PCR were applied at Central diagnostic and research lab, faculty of veterinary medicine, kafrelsheikh Univericity.

TEM, SHV, OXA and CTX-M genes were detected by PCR in E.coli somatic antigen serogroups.

Occurrence of TEM, SHV, OXA and CTX-M genes among $E$. coli serogroups by PCR. 
Characterization Of B-Lactamase Genes In ...

\begin{tabular}{|c|c|c|c|c|c|}
\hline Somatic antigen & Iolates code No. & TEM & SHV & OXA & CTX-M \\
\hline O 55 & S 1 & + & - & - & - \\
\hline O 125 & S 2 & + & - & - & - \\
\hline O 157 & S 3 & - & + & - & - \\
\hline O 126 & S 4 & - & - & - & - \\
\hline Untyped & S 5 & - & - & + & - \\
\hline Untyped & S 6 & + & + & _ & + \\
\hline O 119 & S 7 & + & - & + & - \\
\hline O 78 & S 8 & - & - & - & \\
\hline O 78 & S 9 & - & - & + & - \\
\hline O 1:H 7 & S 10 & + & - & - & + \\
\hline Total & 10 & $\begin{array}{c}5 / 10 \\
(50 \%)\end{array}$ & $\begin{array}{c}2 / 10 \\
(20 \%)\end{array}$ & $\begin{array}{c}3 / 10 \\
(30 \%)\end{array}$ & $\begin{array}{c}2 / 10 \\
(20 \%)\end{array}$ \\
\hline
\end{tabular}

$(+) \quad+v e$

$(-)-V e$

\section{TEM 1080bp}

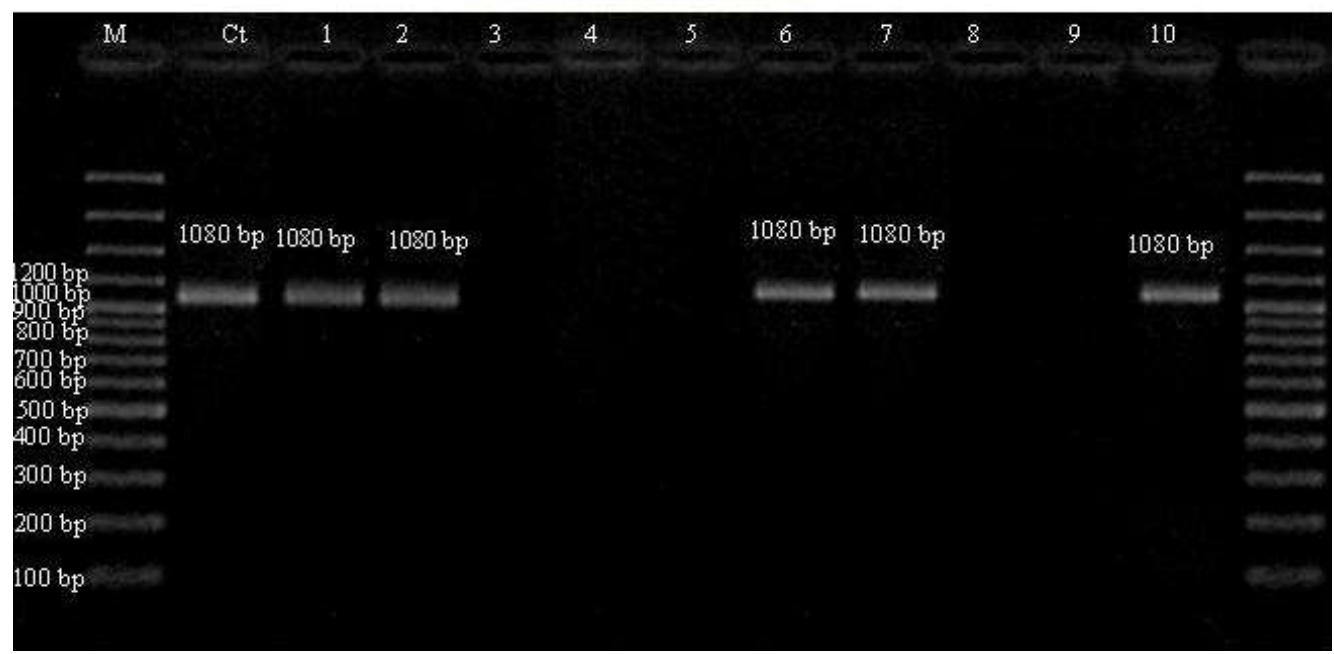

bla ${ }_{\text {TEM }}(1080 \mathrm{bp})$ obtained from isolates with code No $S 1, S 2, S$, S 7 and S 10

$\overline{\text { Kafrelsheikh Vet. Med. J. Vol. } 12 \text { No. } 2 \text { (2014) }}$ 
Fawzia A. Dawoud et., al.

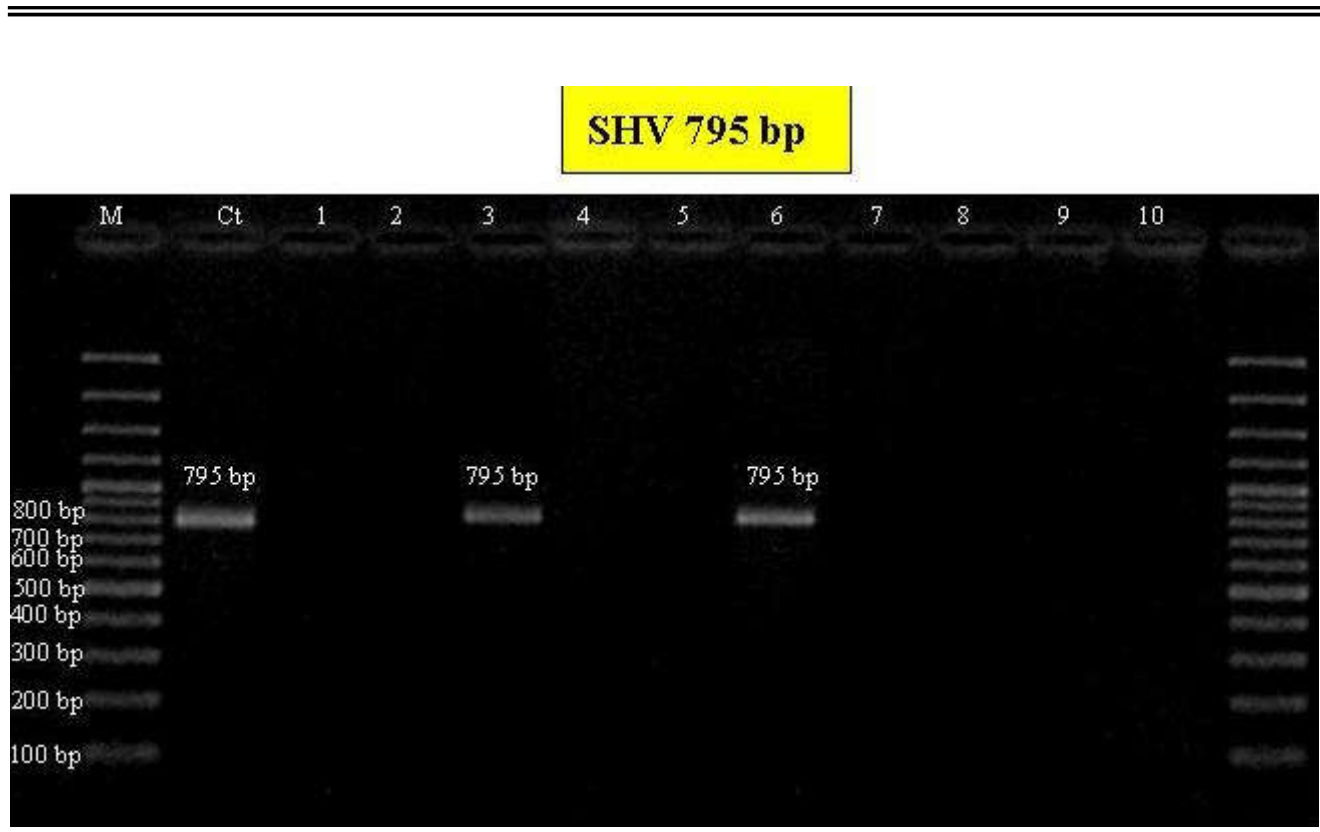

bla SHV (795 bp) obtained from isolates with code No S 3 and S6

\section{OXA 591bp}

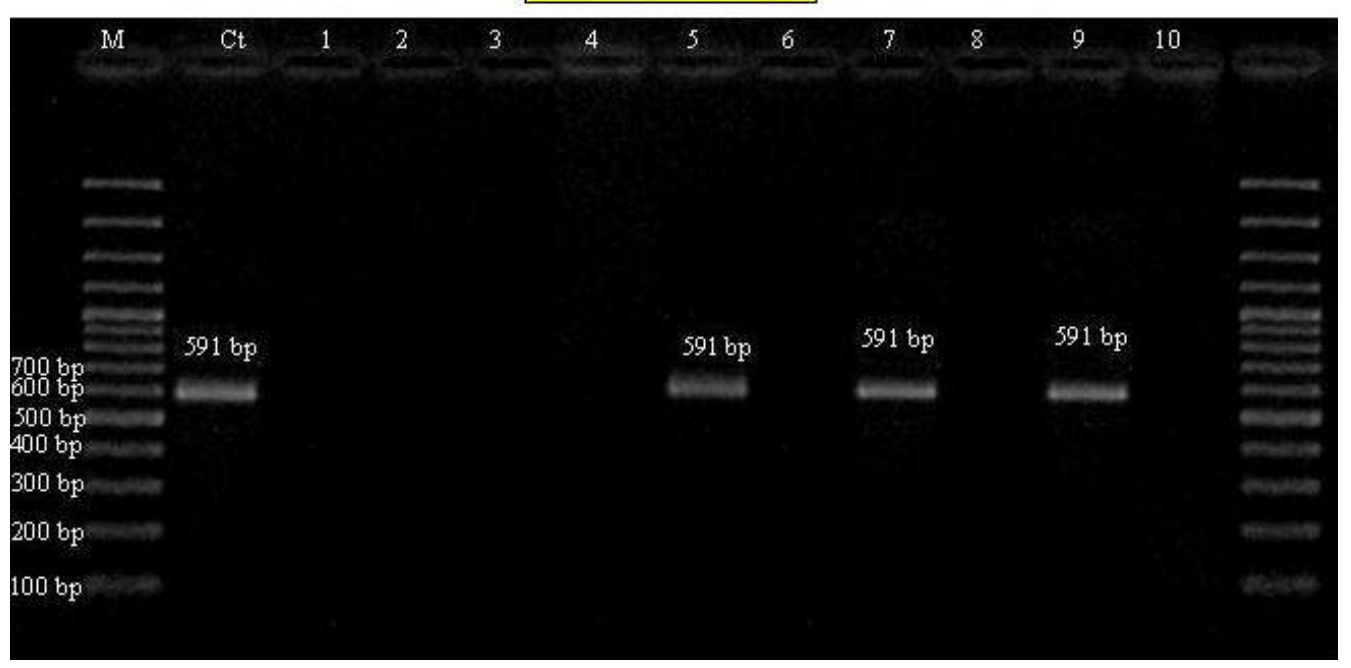

bla oxA (591 bp) obtained from isolates with code No S 5, S 7 and S 9

$\overline{\text { Kafrelsheikh Vet. Med. J. Vol. } 12 \text { No. } 2 \text { (2014) }}$ 


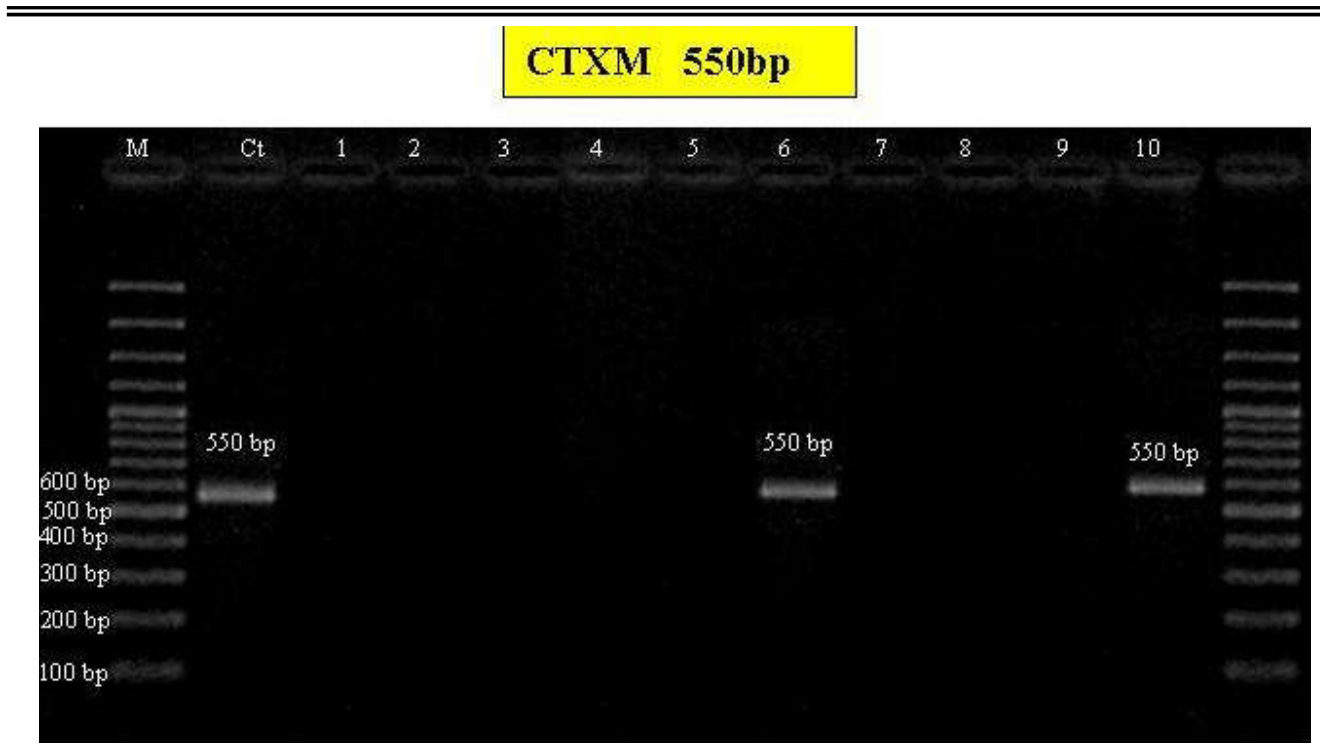

bla ${ }_{\text {СтX-м }}(550 \mathrm{bp})$ obtained from isolates with code No S 6 and S 1

\section{Results of double disc synergy test for detection of B-lactamases:}

Isolates producing CTX-M were tested by DDST and they show +ve result.

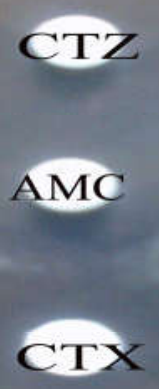

ESBL detected by double Disc diffusion test for $E$. coli isolate showing synergistic inhibition between amoxicillin/ clavulanic Acid (AMC) and both ceftriaxone(CTZ) and cefotaxime (CTX). 


\section{DISCUSSION}

In this study different $E$.coli strains were isolated from briolers with signs of coliseptcemia signs. Concerning the results of this study it wase showed that 105 samples collected from broilers from Gharbia governrate, the positive isolates were 28/105 (26.6\%). E.coli isolates were serogrouped under 7 different $\mathrm{O}$ serotypes $(\mathrm{O} 55, \mathrm{O} 78$,O 125 were the most prevealent serotypes and this nearly similar to results obtained by (M.Alimehr et al,1999).

The $\mathrm{O} 1$ and $\mathrm{O} 55$ serotypes are known to be pathogenic in poultry and are usually isolated from birds with colibacillosis (Gross et al 1988), (Gyimah \& Panigrahy 1988). O 78 serotype is commonly associated with avian colibacillosis on a worldwide scale, and confirm its role as particularly adapted pathogen that permit involvement in extra intestinal infections (Dho-Moulin and Fairbrother, 1999); (La Ragione and Woodward, 2002).

Concerning the result of antimicrobial susceptibility in this study, Cefotaxime was the most effective antimicrobial with high susceptibility percentage $80 \%$, that agree with Liu et al., (2007) reported that E. coli isolates were more sensitive to Cefotaxime, Wafaa.M.G (2012) recorded sensitivety to Cefotaxime $87.5 \%$, that disagree with Sylvester et al., (2006) who recorded low percentage (62\%). Moderate susceptibility to Gentamicin 70\% were recorded and that is nearly similar to Momtaz.H et al., (2012) recorded that all E.coli isolates were susceptible to Gentamicin. E.coli isolates were resistant to Amoxycillin $90 \%$, similarly 
Lambie et al., (2000) isolated E. coli with high resistance to amoxicillin 100\%|, However Giurov, (1985) recorded sensitivity to amoxicillin was $93.8 \%$.

In this study multi drug resistant recorded in all isolated strains. Recording the result of PCR for the detection of $\beta$-lactamase genes among 10 isolated strains, all isolates contain $\beta$-lactamase gens, 5 isolates contain bla тЕм (50\%), 3 isolates contain bla СТХ-м (20\%), 3 isolates contain bla oxA (30\%), 2 isolates contain bla SHV (20\%), 1 isolates contain both bla TEM and bla OXA , 2 isolate contain both bla TEM and bla СтХ-м $_{\text {and }} 1$ isolate contain three gens bla ${ }_{\text {TEM }}, b l a{ }_{\mathrm{SHV}}$, and bla СтХ-м Isolates producing bla СтХ-м were tested by DDST and they show +ve result.

These findings demonstrate that bla тEM was the most dominant gen in $\beta$-lactamase producing broiler isolates , then bla OXA ,bla ${ }_{\text {СTX-M }}$ and finaly bla $\mathrm{SHV}$. Also these results indicate that TEM encoding gene play an increasing role in antibiotic resistance in broilers.

Bla TEM was detected in $32.4 \%$ of APEC strains isolated from chickens suffering from colibacillosis in Korea (Kim et al., 2007), and also from APEC strains isolatedfrom avian colibacillosis in Spain (Mora et al., 2012).

Furthermore,bla $\mathrm{TEM}_{\mathrm{T}}, \mathrm{bla}_{\mathrm{OXA}}$, and bla $\mathrm{CTX}_{\mathrm{CT}-\mathrm{M}}$ were reported in $E$. coli strains isolated from broiler chickens and turkeys in the United Kingdom (Randall et al., 2011), while bla $\mathrm{TEM}_{\mathrm{TE}}$ and bla $\mathrm{SHV}_{\mathrm{SH}}$ were identified in APEC strains isolated from poultry in Australia (Obeng et al.,2012). Isolates producing bla ${ }_{\text {СтХ-м }}$ by PCR showed +ve result by DDST for detection 
of ESBLs. Vercauteren et al., (1997) who stated that sensitivity of double disc diffusion was 96.9\% . Paterson and Bonomo, (2005). Said that ESBLs but not AmpC, clavulanate inhibited the activity of ESBL, leading to enhancement of the zone of inhibition in the area between the amoxicillin / clavulanate disk and any of the third-generation cephalosporin disks. However, in organisms which produce both ESBLs and $\mathrm{AmpC}$, clavulanate may induce hyperproduction of the AmpC $\beta$ lactamase, leading to hydrolysis of the third-generation cephalosporin, masking any synergy arising from inhibition of the ESBL.

\section{CONCLUSION}

It could be concluded that $\beta$-lactams antimicrobial agents are very less effective against E.coli infections in briolers and their usefulness in the treatment of infections due to presence of $\beta$ lactamase genes TEM, OXA, SHV and, CTX-M genes. Further investigations are required to investigate mutation type of $\beta$ lactamases by sequencing and to detect inhibitor resistant TEM genes.

\section{REFERENCES}

- Abraham, E. P., and E. Chain. (1940). An enzyme from bacteria able to destroy penicillin. Nature (London) 146:837.

- Ahmed M. A., Motoi Y., Sato M., Maruyama A., Watanabe H., Fukumoto Y. and ShimamotoT. (2007): Zoo Animals as Reservoirs of Gram-Negative Bacteria Harboring Integrons and Antimicrobial Resistance Genes. American Society for Microbiology. p. 6686-6690. 
- Alimehr.M, Sadeghi-Hashjin .G, Pourbakhsh S.A and K. Nofouzi, (1999): Isolation, Identification and in vitro Susceptibility of Avian Escherichia coli to Selected Fluoroquinolones Faculty of Veterinary Medicine, Urmia University, P.O.Box 1177, Urmia, Iran 2. Razi Vaccine \& Serum Research Institute, P.O. Box 11365-1558, Tehran, Iran.

- Baron E. J. andFinegold S.M. (1990): Bailey and Scott's Diagnostic Microbiology. 8th edition, Mosby Co., St. Louis, Balitimore.

- Bauer A.W., Kirby W.M.M., Sherris J.C. and Truck M. (1966): Antibiotic susceptibility testing by standardized single disk method. Amer. J. Clin. Pathol. 45: 493-96.

- BradfordP.A. (2001): Extended-spectrum $\beta$-lactamases in the 21st centurycharacterization, epidemiology, and detection of this important resistance threat. ClinMicrobiol Rev; 14: 933-951.

- Bradford, P. A. (2005): $\beta$-Lactamases in the $21 \mathrm{st}$ century: characterization, epidemiology, and detection of this important resistance threat. Clin. Microbiol. Rev. 14:933-951.

- Cruickshank R., Duguiel J.P., Marmion B.P. and Swain R.H.A. (1975): Medical microbiology. 12th ed. Vol. II Churchill Living stone, Edenburg, London and New York. Des; 5:895-913.

- Dho-Moulin, M., Fairbrother, J.M., (1999). Avian pathogenic Escherichia coli (APEC). Vet. Res. 30, 299-316. 
- Giurov B. (1985): Sensitivity of drugs of E. coli strains isolated from poultry with colisepticemia. Vet. Med. Nauki., 22 (5):16-24.

- Gross, W.G., (1994): Diseases due to Escherichia coli in poultry. In: Escherichia coli in domestic animals and humans. C. L. Gyles, ed. CAB International, Wallingford, U.K. pp: 237-259.

- Gyimah, J.E. and Panigrahy, B.(1988). Adhesin-receptor interactions mediating the attachment of pathogenic Escherichia coli to chicken tracheal epithelium. Avian Diseases 32:74-78

- Clinical and Laboratory Standards Institute (2005): Performance standards for antimicrobial susceptibility testing; 15th informational supplement. National Committee for Clinical Laboratory Standards, Wayne.

- Higgins, C.F., (2007): Multiple molecular mecanisms for multidrug resistance trancporters. Nature 446,749-757.

- Kim, T.E., Jeong, Y.W., Cho, S.H., Kim, S.J., Kwon, H.J., (2007). Chronological studyof antibiotic resistances and their relevant genes in Korean avian pathogenicEscherichia coli isolates. J. Clin. Microbiol. 45, 3309-3315

- Lambie N., Ngeleka M., Brown G., and Ryan J. (2000): Retrospective study on $E$. coli infection in broilers subjected to postmortem examination and antibiotic resistance of isolates in Trinidad. Avian Dis., 44 (1): 155-160. 
- La Ragione, R.M., Woodward, M.J.,( 2002). Virulence factors of Escherichia coli serotypes associated with avian colisepticaemia. Res. Vet. Sci. 73, 27-35.

- Liu J.H., Wei S.Y., Ma J.Y., Zehg Z.L., Lu .H., Yang G.X. and ChemZ.L. (2007): Detection and characterization of CTX-M and CMY-2 $\beta$-Lactamases among E. coli isolates from farm animals in Guangdong province of China. International Journal of Antimicrobial Agents, 29: 576-581.

- Livermore D.M. (1998): $\quad \beta$-lactamase-mediated resistance and opportunities for its control. J. Antimicrob. Agents 41 (Suppl. D): 25-41.

- Mora, A., López, C., Herrera, A., Viso, S., Mamani, R., Dhabi, G., Alonso, M.P., Blanco,M., Blanco, J.E., Blanco, J., (2012): Emerging avian pathogenic Escherichia coli strains belonging to clonal groups O111:H4-D-ST2085 and O111:H4-D-ST117with high virulence-gene content and zoonotic potential. Vet. Microbiol. 156,347-352.

- Obeng, A.S., Rickard, H., Ndi, O., Sexton, M., Barton, M.A.,(2012): Antibiotic resistance,phylogenetic grouping and virulence potential of $E$. coli isolated fromthe faeces of intensively farmed and free range poultry. Vet. Microbiol. 154,305-315.

- Randall, L.P., Clouting, C., Horton, R.A., Coldham, N.G., Wu, G., Clifton-Hadley, F.A.,Davies, R.H., Teale, C.J., (2011): Prevalence of Escherichia coli carrying extended-spectrum $\beta$-lactamases (CTX-M and TEM-52) from broiler chickens and turkeysin Great Britain between 2006 and 2009. J. Antimicrob. Chemother. 66, 86-95. 
- Sunde M. and Sorum H. (1999): Characterization of integrons in E. coli of the normal intestinal flora of swine. Microb. Drug Resist. 5:279-287.

- Sylvester S. A., Singh S. D. and Dash B. B. (2006): Isolation, serotyping and antibacterial sensitivity of $E$. coli from cases of colibacillosis in poultry. Indian Journal of Veterinary Medicine. 6(1): 38-40.

- Wafaa M.G.(2012): Occurrence Of Antibiotic Resistance Genes Among E.coli Serotypes Isolated From Broilers. Master thesis, Zagaziguniveristy.

- Batchelor, M., Threlfall, E.J. \&Liebana, E. (2005). Cephalosporin resistance among animal-associated Enterobacteria: acurrent perspective. Expert Rev Anti Infect Ther 3, 403-417

- Momtaz.H, Rahimi. E,Moshkelani. S, (2012). Molecular detection of antimicrobial resistance genes in E.coli isolated from slaughtered commercial chickens in Iran. Vetrinarni Medicina.57: 193-197.

- Vercauteren E., Descheemaeker P., and Ieven M. (1997): Comparison of screening methods for detection of extended-spectrum beta-lactamases and their prevalence among blood isolates of Escherichia coli and Klebsiella spp. in a Belgian teaching hospital. J. Clin. Microbiol. $35: 2191-2197$. 


\section{الملخص العربي}

نتيجة الاستخدام المكثف لأدوية البيتالاكتام ظهرت مقاومة الميكروب القولوني عن طريق إنتاج أنزيم البيتالاكتاميز • ولذلك أجريت هذه الدراسة لتصنيف جينات البيتالاكتيميز في الميكروب القولوني المعزول من بداري التسمين حيث نم عزل الميكروب القولوني من 1 مع عينه من مزارع

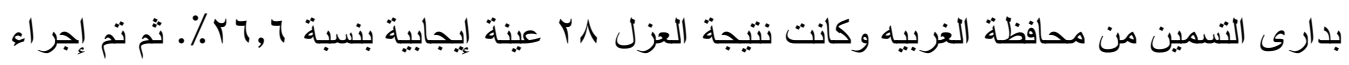
التصنيف السيرولوجى لـ 10 معزولة أخذت عشوائيا حيث صنفت هذه المعزو لات إلى V عترات مختلفة (O 55,O 125, O 126, O157, O78, O1:H7, O119:H6). و عند إجر اء اختبار حساسيه للعتر ات المعزولة لأنو اع مختلفة من المضادات الحيوية وجد أن السيفوتاكسيم، الجينتاميسين والاموكسيسيللين وحمض كلافيولينيك أكثر المضادات الحيوية فعاليه، بينما أوضحت العزلات أكثر مقاومه ضد الاموكسيسيللين. وعند إجر اء اختبارات الحامض النووي وذلك بطريقة اختبار أنزيم البلمرة المنسلسل لتحديد جينات البتلاكتاميز في الميكروب القولوني أظهرت أن جميع العزلات تحتوى على جينات البيتالاكتاميزال CTX-M SHV ، OXA TEM بنسبة

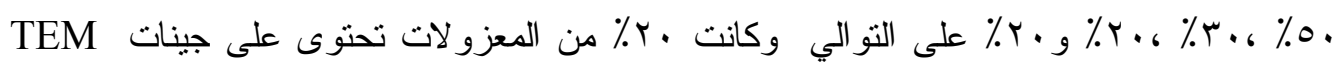
، TEM معا و • (1) تحتوى على جينات OXA ،TEM-M، OXA ، SHV ميكروب الاشريشيا القولونى للمضادات الميكروبية يليه جين الـ SHV و CTX-M ، OXA . ومن هذه النتائج نستتتج أن المضادات الحيوية التي تحتوى على بيتالاكتام غير فعاله في علاج هذه المعزولات فهي غير مجدية في علاج الإصابة من ميكروب الاثشيرشيا القولونية وذلك لوجود

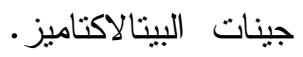

